\title{
Frontal lobe dysfunctions, dissociation, and trauma self-reports in forensic psychiatric patients
}

Citation for published version (APA):

Cima, M. J., Merckelbach, H. L. G. J., Klein, B., Shellbach-Matties, R., \& Kremer, K. (2001). Frontal lobe dysfunctions, dissociation, and trauma self-reports in forensic psychiatric patients. Journal of Nervous and Mental Disease, 189(3), 188-190. https://doi.org/10.1097/00005053-200103000-00008

Document status and date:

Published: 01/01/2001

DOI:

10.1097/00005053-200103000-00008

Document Version:

Publisher's PDF, also known as Version of record

\section{Please check the document version of this publication:}

- A submitted manuscript is the version of the article upon submission and before peer-review. There can be important differences between the submitted version and the official published version of record. People interested in the research are advised to contact the author for the final version of the publication, or visit the DOI to the publisher's website.

- The final author version and the galley proof are versions of the publication after peer review.

- The final published version features the final layout of the paper including the volume, issue and page numbers.

Link to publication

\footnotetext{
General rights rights.

- You may freely distribute the URL identifying the publication in the public portal. please follow below link for the End User Agreement:

www.umlib.nl/taverne-license

Take down policy

If you believe that this document breaches copyright please contact us at:

repository@maastrichtuniversity.nl

providing details and we will investigate your claim.
}

Copyright and moral rights for the publications made accessible in the public portal are retained by the authors and/or other copyright owners and it is a condition of accessing publications that users recognise and abide by the legal requirements associated with these

- Users may download and print one copy of any publication from the public portal for the purpose of private study or research.

- You may not further distribute the material or use it for any profit-making activity or commercial gain

If the publication is distributed under the terms of Article $25 \mathrm{fa}$ of the Dutch Copyright Act, indicated by the "Taverne" license above, 


\section{Brief Reports}

\section{Frontal Lobe Dysfunctions, Dissociation, and Trauma Self-Reports in Forensic Psychiatric Patients}

A recurrent finding in psychiatric research on dissociative symptoms is that these symptoms are more prevalent in female than in male psychiatric patients (e.g., Ross, 1997). Some authors have argued that this skewed sex distribution is an artificial phenomenon (Putnam, 1989; Ross, 1997). They suggest that compared with women with dissociative symptoms, men with dissociative symptoms are more likely to engage in antisocial behavior and, therefore, are more likely to be found in correctional institutions than in psychiatric treatment facilities. There are, indeed, some indications that dissociative symptoms are quite common among male prison inmates. For example, Snow and associates (1996) noted that their sample of male inmates exhibited higher mean scores on the Dissociative Experiences Scale (DES; Bernstein and Putnam, 1986) than general population samples. Research in this domain is often guided by the more or less implicit assumption that dissociative symptoms in offenders and prison inmates must have a similar etiology as the dissociative symptoms seen in noncriminal psychiatric patients. Thus, it is often believed that in both populations, dissociative symptoms originate from traumatic childhood events (e.g., child sexulal abuse). With the possible exception of the small-scale study by Lewis and associates (1997), there have been no attempts to subject this assumption to empirical testing. Also, the possibility that dissociative symptoms of offenders and prison inmates may have a neurological background has been largely overlooked. Meanwhile, this possibility warrants systematic research. Germane to this issue are studies showing that frontal dysfunctions are intimately linked to violent behavior and dissociative states (e.g., Evans and Claycomb, 1999),

The present study examined to what extent dissociative symptoms in a heterogeneous group of psychiatric prison inmates are associated with childhood trauma and/or frontal functioning. Information about the traumatic background of the patients was not only obtained by having the patients fill out a standardized self-report instrument of childhood trauma but also by having an independent and blind judge rating patients' records (see, for a similar procedure Sanders and Giolas, 1991). Patients also completed a measure on fantasy proneness. This information was obtained in order to evaluate whether fantasy proneness might contribute to the link between dissociation and self-reports of trauma (Merckelbach and Muris, in press).

\section{Methods}

Patients. Participants were 30 male inmates of a German psychiatric correctional institute. Their mean age was 39 years (range: 19 to 66 years). Ten patients had committed murder, whereas the remaining patients were convicted for sexual offenses (14 patients), aggressive criminal acts ( 2 patients), fraud, arson, and/or exhibitionism ( 4 patients). As to their psychiatric diagnoses, a majority of the patients ( 23 patients; 77\%) met the DSM-IV (American Psychiatric Association, 1994) criteria for one or more personality disorders, in particular disorders of the Cluster $B$ type. The most common axis I diagnoses were sexual disorder (17 patients; $57 \%$ ) and substance abuse ( 5 patients; $17 \%$ ). Two patients had a diagnosis of schizophrenia (7\%), and one patient suffered from obsessive-compulsive disorder (3\%). Patients volunteered to participate in several test sessions.

Measures. During one test session, patients completed German versions of the 28-item Dissociative Experiences Scale (DES; Bernstein and Putnam, 1986; Cronbach's alpha $=0.88$ ), the 25-item Short Form of the Childhood Trauma Questionaire (CTQ; Bernstein et al., 1994; Cronbach's alpha $=0.68$ ), and the 25-item Creative Experiences Questionnaire (CEQ; Merckelbach et al., 2000), which is a measure of fantasy proneness. During a second session, patients were administered four tasks of The Behavioral Assessment of Dysexecutive Syndrome (BADS) test battery (Wilson et al., 1996). The following tasks were selected: the Rule Slift Cards test, which measures cognitive flexibility; the Key Search test, which provides an index of the ability to plan and monitor effective search strategies; the Temporal Judgment test, which measures reasoning about time durations; and the Zoo Map test, which measures the ability to plan a route. For each task, a profile score is given (with a maximum of 4 and a minimum of 0 ), and these can be summed to obtain a total score, with lower scores indicating poorer executive (i.e., frontal) functioning. Completion of the four BADS tasks took about 1 hour.

Extensive hospital records of all 30 patients were available. Patients' records, including psychotherapists' notes and summaries of family background and social history, were subjected to close inspection to reach an independent assessment as to the traumatic background of each individual patient. Ratings were made by a therapist who was blind as to patients' DES or CTQ scores. Each childhood trauma category (i.e., physical abuse, emotional abuse, sexual abuse, emotional neglect, and physical neglect) was rated on a dichotomous scale $(0=$ indications for abuse/neglect absent; 1 = indications for abuse/neglect present).

\section{Results}

Mean scores (and SDs) of the patients on the DES, CTQ, $\mathrm{CEQ}$, and BADS were 33.5 (20.4), 62.1 (26.7), 9.0 (3.6), and 7.0 (2.7), respectively. Mean trauma rating based on hospital records was $2.7(\mathrm{SD}=1.7)$. Note that the mean DES score of the patients was well above the population mean (mean = 11.6; $\mathrm{SD}=10.6 ;$ Van IJzendoorn and Schuengel, 1996: $t[1486]$ 
TABLE 1

Pearson Correlations between Dissociation (DES), SelfReported Childhood Trauma (CTQ), Fantasy Proneness (CEQ), and Executive Performance (BADS) $(N=30)$

\begin{tabular}{llll}
\hline & DES & CTQ & CEQ \\
\hline CTQ & -.07 & & \\
CEQ & -.06 & .25 & \\
BADS & $-.39^{*}$ & $.34^{*}$ & .02 \\
\hline
\end{tabular}

$* p<.05$ (one-tailed).

$=10.9, p<.01$ ), indicating high dissociation levels in our patient sample. Likewise, patients' CTQ scores were considerably higher than those reported for a sample of healthy young adults (mean $=36.8, \mathrm{SD}=7.4$; Merckelbach et al. ${ }^{3}$ : $t[137]=8.8 ., p<.01)$. Interestingly, there was a significant correlation between patients' CTQ scores and trauma ratings based on hospital charts $(r=.53, p<.01)$. Mean score of the patients on fantasy proneness (CEQ) did not differ from the mean scores of normal participants reported in previous studies (e.g., mean $=8.3, \mathrm{SD}=4.2$; Merckelbach et al., 2000: $t[180]<1.0, \mathrm{NS})$. Total BADS scores of our patients were significantly below that of the patient sample described by Wilson et al. (1996; mean $=8.9$; $\mathrm{SD}=4.8: t[106]=2.1, p<$ .05). This suggests that our sample exhibited considerable executive (i.e., frontal) deficits.

Table 1 shows Pearson product-moment correlations between the various psychometric measures. Note that DES scores were not related to self-reported childhood trauma on the CTQ. The correlation between DES and fantasy proneness (CEQ) did not attain significance. However, there was a significant association between DES and BADS performance: poorer performance on frontal tasks was found to be related to higher DES scores $(r=-.39 p<.01)$. In addition, BADS performance and CTQ were found to be related such that better frontal functioning was associated with more selfreports of childhood trauma on the CTQ. In passing, it should be noted that neither DES scores, nor fantasy proneness (CEQ) scores were linked to trauma ratings based on hospital charts ( $r=-.13$ and $r=.07$, respectively; both NS).

\section{Discussion}

The results of the current study can be summarized as follows. To begin with, in keeping with earlier work (e.g., Bliss and Larson, 1985; Snow et al., 1996), our study found heightened levels of dissociation in criminal offenders. Second, self-reports of childhood trauma as indexed by the CTQ were also quite common among the criminal offenders in our study. These self-reports correlated significantly with trauma ratings based on hospital charts. Third, in contrast to prevailing notions (e.g., Snow et al., 1996), neither self-reported childhood traumas nor trauma ratings based on hospital charts were linked to dissociative symptoms. Fourth, unlike previous studies (e.g., Merckelbach et al., 2000), no evidence was found to suggest that fantasy proneness (CEQ) contributes to dissociative symptoms or trauma self-reports.

\footnotetext{
${ }^{3}$ Merckelbach H, Horselenberg R, Schmidt H (submitted) Modelling the connection between self-reported trauma and dissociation in a student sample.
}

Fifth, poor frontal functioning as indexed by the BADS was found to be linked to dissociative symptoms. Finally, a curious finding was the positive correlation between frontal functioning and self-reports of trauma. One way to interpret this is to argue that patients who exhibit frontal lobe dysfunctions are less able to provide articulate self-reports of childhood trauma. Note, however, that such a line of reasoning cannot account for the simultaneous absence of a trauma-dissociation and presence of a frontal dysfunctiondissociation link. If frontal deficits undermine self-reports of trauma, they should also interfere with self-reports of dissociative symptoms. This pattern should have increased the probability of detecting a trauma-dissociation connection, yet such a connection was not evident.

\section{Conclusion}

The current results support the view that dissociative symptoms might be quite common among male prison inmates (e.g., Ross, 1997). However, they are difficult to reconcile with a simple version of the trauma-dissociation model according to which dissociative symptoms directly stem from traumatic childhood experiences (e.g., Snow et al., 1996). Rather they seem to suggest that in this particular group, dissociative symptoms might be related to frontal deficits. In more general terms, our results underline the importance of recent studies that sought to elucidate the neuropsychology of dissociative symptoms (e.g., Lipsanen et al., 2000). Dissociation is thought to reflect an inability to integrate different psychological functions (e.g., memory, emotion, awareness; e.g., Bernstein and Putnam, 1986). It may well be the case that not only a traumatic background, but. also frontal deficits contribute to such an inability.

\section{References}

American Psychiatric Association (1994) Diagnostic and statistical manual of mental aisorders (4th ed). Washington, DC: Author.

Bernstein DP, Fink L, Handelsman L, Fook J, Lovejoy M, Wenzel K, Saparetor E, Ruggiero J (1994) Initial reliability and validity of a new retrospective measure of child abuse and neglect. Am J Psychiatry 151:1132-1136.

Bernstein EM, Putnam FW (1986) Development, reliability, and validity of a dissociation scale. $J$ Nerv Ment Dis 174: 727-735.

Bliss EL, Larson EM (1985) Sexual criminality and hypnotizability. J Nerv Ment Dis 173:522-526.

Evans JR, Claycomb S (1999) Abnormal QEEG patterns associated with dissociation and violence. $J$ Neurother $3: 21-27$.

Lewis DO, Yeager CA, Swica Y, Pincus JH, Lewis M (1997) Objective documentation of child abuse and dissociation in 12 murderers with Dissociative Identity Disorder, Am I Psychiatry $154: 1703-1710$

Lipsanen T, Lauerma H, Peltola P, Kallio S (2000) Associations among dissociative experiences, handedness, and demographic variables in a nonclinical population. $J$ Nev Ment Dis 188:422-427.

Merckelbach H, Muris P (in press) The causal link between selfreported trauma and dissociation: A crítical review. Behav Res Ther.

Merckelbach H, Rassin E, Muris P (2000) Dissociation, schizotypy, and fantasy proneness in undergraduate sturlents. $J$ Ner Ment Dis 188:428-431.

Putnam FW (1989) Diagnosis and treatment of multiple yetsonality disorder: New York: Guilford. 
Ross CA (1997). Dissociative identity disorder: Diagnosis, clinical features, and treatment of multiple personality. New York: Wiley.

Sanders B, Giolas MH (1991) Dissociation and childhood trauma in psychologically disturbed adolescents. Am t Psychiatmy 148:50-54.

Snow MS, Beckman D, Brack G (1996) Results of the Dissociative Experiences Scale in a jail population. Dissociation 9:98103.

Van IJzendoorn MH, Schuengel C (1996) The measurement of dissociation in normal and clinical poplations: Meta-analytic validation of the Dissociative Experiences Scale (DES). Clin Psychol Rev 16:365-382.

Wilson BA, Alderman N, Burgess PW, Emslie HE, Evans JJ (1996) Behavioural assessment of the dysexecutive symdrome. Bury St. Edmunds, England: Thames Valley Test Company.

Maaike Cima, M.Sc., ${ }^{1}$ Flarald Merckelbach, Ph.D.,2 Brigitte Klein, Ph.D., ${ }^{1}$

Rolf Shellbach-Matties, M.D., ${ }^{1}$ and Karl Kremer, M.D. ${ }^{1}$

\footnotetext{
${ }^{1}$ Rheinische Landesklinik, Düren, Germany.

${ }^{2}$ Department of Experimental Psychology and Faculty of Law, Maastricht University, The Netherlands. Send reprint requests to Prof. Dr. F. Merckelbach, Department of Experimental Psychology, P.O. Box $616,6200 \mathrm{MD}$, The Netherlands.
}

\section{Transliminality, Brain Function, and Synesthesia}

Transliminality is a "hypothesized tendency for psychological material to cross thresholds into or out of consciousness" (Thalbourne and Houran, 2000, p. 861). This construct was already anticipated as early as William James (1902/ 1982), but it was only recently given empirical definition and attempted measurement by Thalbourne (1998) in terms of a 29-item dichotomous scale. Representative items from the scale are available in previous publications (Thalbourne, $1999,2000 \mathrm{a}$ ). It is important to note that these 29 test-items, which share a common underlying factor, span nine domains: hyperesthesia, (fleeting) hypomanic or manic experience, fantasy-proneness, absorption, creative personality, positive (and perhaps obsessional) attitude toward dream interpretation, mystical experience, paranormal belief and experience, and magical thinking. Consequently, the type of psychological material crossing into conscious awareness involves large amounts of imagery, ideation, and affect. Elsewhere (Houran and Thalbourne, 2001, in press), we have speculated about the neuropsychological basis of transliminality. Because transliminal experience resembles and positively correlates with schizotypal and schizophrenic-like experience (Thalbourne, 1998; Thalbourne et al., 1997), it may be that similar processes are operating.

\section{A Neuropsychological Basis for Transliminality}

Traditionally, schizotypal and schizophrenic-like experience have been conceived as a deficit in cognitive inhibition, or in selective attention tasks, in that the cognitive mechanisms responsible for active suppression (or gating) of irrelevant information from conscious awareness are defective, i.e., weak or erratic (Braff et al., 1999; Lieb et al., 1996; Perry et al., 1999; Peters et al., 2000; Swerdlow and Geyer, 1998; Williams and Beech, 1997). Houran and Thalbourne (in press $\mathrm{a}$, in press b) attribute this poor gating to a much greater degree of "interconnectedness" or "fluidity" in the brains of highly transliminal persons-the gateways that normally operate to regulate conscious and unconscious processing may be open to an unusually high degree. Neurological interconnectedness is necessary for psychological integration, but integration will be compromised (Nasrallah, 1985) when the interconnectedness is too liberal (O'Kusky et aI., 1988; Witelson, 1985).

Modern-day behavioral scientists eschew the term "ego," owing to its psychoanalytic origin, but "ego" and "ego strength" have been used purely to describe cognitive functions and personality characteristics (Alias, 1974, 2000; Perry et al., 1995; Stone, 1980). Ego may be viewed as the central "magnetic sphere" of the psyche that integrates and coordinates the autonomous cognitive fragments consisting of "percept units" and (reactive and nonreactive) "thought units" (Alias, 1974), and ego strength as the centripetal, cohesive force with which the integration and coordination of the cognitive fragments are prosecuted (Alias, 2000). Kaplan and Sadock (1998) write, "first described by Herman Nunberg in 1931, the synthetic function refers to the ego's capacity to integrate diverse elements into an overall unity. . . [It] involves organizing, coordinating, and generalizing or simplifying large amounts of data" (p. 218). Freeman (1960) proposed that damage to the perceptual system of ego leads to a failure of its screening function. As a result the individual can no longer insulate a train of thought from extraneous sensory stimulation (i.e., deficient sensorimotor gating: Braff et al., 1999; Perry et al., 1999; Swerdlow and Geyer, 1998). Percepts and images now compete for attention with already existing thoughts.

Alias (1974) hypothesized that a train of thought is an orderly linked chain made up of different autonomous units like amino aids in a protein molecule; the correct position of any unit, as well as the pace with which these units enter into consciousness for the organization of a stream of thought, is directed by the ego; this operation is largely automatic, instantaneous and without subjective awareness. If the ego is weak, as in schizotypy and schizophrenia, this arrangement becomes impaired and the "thought units" will "express" themselves, their independent existence, often in a disordered fashion (loose associations) either individually, or more collectively, to a highly variable extent depending upon the degree of ego-weakening, anxiety level, learning (by conditioning), and the state of arousal.

Andreasen et al. (1998) coined the term, "cognitive dysmetria," meaning "difficulty in prioritizing . . . coorclinating, and responding to information." They postulated that a disruption in the circuitry among nodes located in the prefrontal regions, the thalamic nuclei, and the cerebellum produces cognitive dysmetria. This poor "mental coordination" is a fundamental cognitive deficit in schizophrenia and can account for its broad diversity of symptoms (Andreasen et al., 1998). A similar pathophysiology was proposed in connection with the schizophrenia-like episodes of temporal lobe epilepsy. Again, a broad range of interictal symptoms, 